\title{
高炉下部コークス充填層における未燃チャーの反応 および消費挙動
}

\author{
佐藤 道貴* ·深田 喜代志* ·有山 達郎* ·板垣 省三*・村井 亮太*
}

Reaction and Consumption Behavior of Unburnt Char in Lower Part of Blast Furnace

Michitaka Sato, Kiyoshi Fukada, Tatsuro Ariyama, Shozo Itagaki and Ryota Murai

Synopsis : To clarify the gasification and consumption behavior of unburnt char ascending in the coke packed bed in the lower part of the blast furnace, char reaction-consumption model has been newly developed considering the average residence time and co-gasification with coke particles. The chemical reaction rate constant has been determined based on the high temperature experiments on the char injection into the coke packed bed.

From the analyses using this model, the following results were obtained.

(1) The mean ascending velocity of char particles with the diameter of $20 \mu \mathrm{m}$ was approximately $0.3 \mathrm{~m} / \mathrm{s}$, and it was smaller than the actual gas velocity by one order of magnitude, suggesting the char particles had fairly long residence time in the blast furnace.

(2) The consumption rate of char became lower with the increase in the solid-gas loading ratio. This was considered to be caused by the higher ascending velocity which resulted from the successive renewal of stagnant particles in the packed bed by supplied char particles.

( 3 ) According to the examination of char consumption behavior along the blast furnace height, char discharge rate from the top of the thermal reserve zone could be reduced considerably by decreasing char exhaust rate from the raceway. This phenomenon resulted from the increase in the consumption rate throughout the height, due to the decrease in the solid-gas loading ratio. Therefore, to suppress the char exhaustion from the top, it was necessary to improve the combustion efficiency in the raceway at higher injection rate of pulverized coal.

Key words: ironmaking; blast furnace; pulverized coal injection; unburnt char; coke packed bed; gasification; char consumption behavior.

\section{1. 緒言}

高炉への微粉炭吹込みは, 溶銑製造コストの低減, コー クス炉の寿命延長に有効であることから国内の全高炉で実 施され，現在では高炉の基幹技術ともなっている。さらに， 本技術はコークスに比べて水素を多く含む石炭を直接使用 でき，炭酸ガスの発生量抑制に効果があることから，今後 ますます多量吹込みのニーズが高まると予測される。

安定した多量吹込みを実現するためには，吹き込まれた 微粉炭が全量, 炉内で有効利用されることが必須条件であ る。このような条件を達成するための基本的な操作因子を 適切に制御する観点から，微粉炭の燃焼挙動 ${ }^{1,2)}$ ならびに 未燃チャーの充填層内における運動・ガス化反応に関する 多くの研究 ${ }^{3-10)}$ が実施され，微粉炭の吹込みから消失に至 る挙動が次第に明らかにされつつある。しかし，後者につ いてはチャ一粒子の反応速度の測定 ${ }^{3,4)}$ や冷間充填層にお ける流動解析 ${ }^{5-9}$ など, 個別の研究は多数なされているも のの, 高温のコークス充填粒子間を飛翔運動する各個別粒 子の平均的な滞留時間とガス化反応を同時に考慮して，そ の消費挙動を定量的に検討した例はない。

そこで本研究では，未燃チャーの運動モデルとして，充
填層内の平均滞留時間を考慮する移動モデル9用い，こ れにチャーのガス化反応を新たに付与した反応消費モデル を開発した。ガス化反応としては $\mathrm{CO}_{2}$ および $\mathrm{H}_{2} \mathrm{O}$ との反応 が考えられるが, 高炉下部では $\mathrm{H}_{2} \mathrm{O}$ の体積分率は低いた め ${ }^{11)}$, より主要な役割を果たすと考えられる $\mathrm{CO}_{2}$ との反応 を取り上げた。さらにガス化反応速度については，高炉下 部を模擬したコークス充填層へのチャーの吹込み試験を行 い, 実測值と反応消費モデルによる計算結果を比較検討す ることにより，化学反応速度定数を推算した。そして，得 られた反応速度式を用いて高炉下部コークス充填層におけ る未燃チャーの消費挙動について検討した結果, チャーの 全量を炉内で消費させる条件について重要な知見が得られ たので報告する。

\section{2. 高温反応試験}

\section{$2 \cdot 1$ 試験条件}

コークス充填層内における未燃チャーのガス化反応挙動 を調査するために用いた高温反応試験装置の概要を Fig. 1 に示す。本装置はガスおよびチャーの供給系と排出系, 加 熱炉から構成される。実験はまず，加熱炉内に設置した内

平成 12 年 8 月 28 日受付 平成 12 年 12 月 21 日受理 (Received on Aug. 28, 2000; Accepted on Dec. 21, 2000)

* NKK 総合材料技術研究所 (Materials \& Processing Research Center, NKK Corp., 1 Kokan-cho Fukuyama 721-8510) 


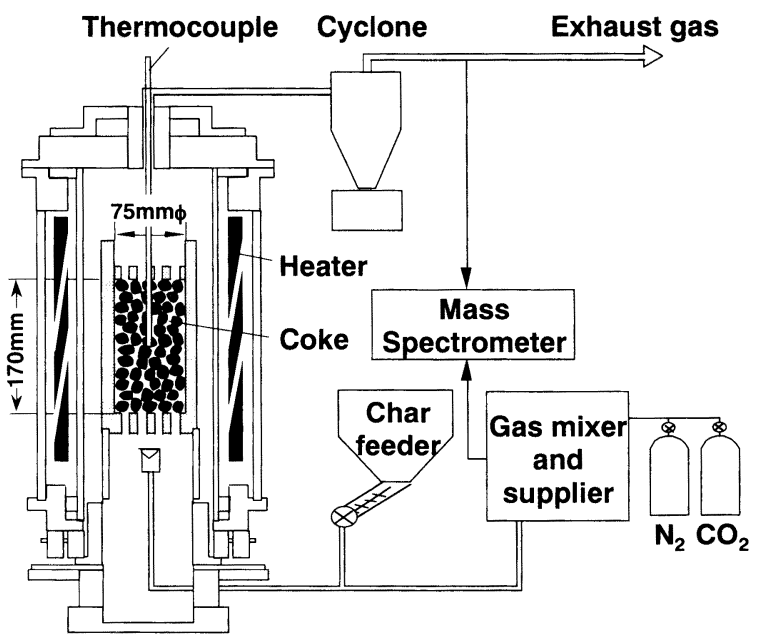

Fig. 1. Schematic illustration of high temperature test furnace

Table 1. Properties of samples.

\begin{tabular}{cccccccc}
\hline & \multicolumn{3}{c}{$\begin{array}{c}\text { Proximate analysis } \\
\text { (db, mass\%) }\end{array}$} & \multicolumn{3}{c}{$\begin{array}{c}\text { Ultimate analysis } \\
\text { (d.a.f., mass\%) }\end{array}$} \\
& VM & FC & Ash & \multicolumn{1}{c}{ C } & \multicolumn{1}{c}{ H } & \multicolumn{1}{c}{ O } \\
\hline Coal & 33.2 & 57.0 & 9.8 & 81.3 & 5.2 & 10.9 \\
Char & 13.5 & 62.2 & 24.3 & 90.0 & 2.6 & 4.8 \\
Coke & 0.8 & 88.7 & 10.5 & 97.8 & 0.6 & 0.9 \\
\hline
\end{tabular}

径 $75 \mathrm{~mm} \phi$ のアルミナるつぼに 7.5 9 mmのコークスを $350 \mathrm{~g}$ （充填層高さ $h=0.17 \mathrm{~m}$, 充填層の空隙率約 0.53 ）充 填し, 次いで, $\mathrm{N}_{2}$ を流しながら所定の温度まで昇温した。 温度制御はコークス充填層内部に挿入した熱電対の温度で 行った。その後，速やかに $\mathrm{CO}_{2} / \mathrm{N}_{2}$ 混合ガスに切り替え， 同時に $\mathrm{N}_{2}$ に同伴させたチャーをるつぼ下面から吹き込ん だ。反応温度は $1000^{\circ} \mathrm{C}$ と $1250^{\circ} \mathrm{C}$ の 2 水準とし，供給ガス の $\mathrm{CO}_{2}$ 濃度およびチャー吹込み量を種々に変化させた。吹 込み時間は反応温度が $1000^{\circ} \mathrm{C}$ の時は 60 分， $1250^{\circ} \mathrm{C}$ の時は 15 分とした。チャーは高炉のレースウェイから発生した ものを模擬するため，高炉のブローパイプおよび羽口部を 模擬できるホットモデル1)用いて $1200^{\circ} \mathrm{C}$ の熱風中であら かじめ燃焼させ，サイクロンで回収したものを供試試料と した。チャーの調和平均径は顕微鏡下での観察の結果，約 $22 \mu \mathrm{m}$ であった。実験ではこれを 44〜63 $\mu \mathrm{m}$ (平均 $52 \mu \mathrm{m}$ ) に調整して用いた。本研究に用いた微粉炭, チャーおよび コークスの工業分析值および化学分析值を Table 1 に示す。 また，代表的な実験条件を Table 2 に示す。実験中は排ガ ス組成をモニタ一するとともに，未反応のチャーをサイク ロンで捕集した。実験終了後は $\mathrm{N}_{2}$ 気流中で冷却後, 充填 コークスを回収するとともに，コークス粒子間に付着・堆 積しているチャーをはけで分離，回収した。そして，実験 前後の工業分析值から次式により，未燃チャーとコークス それぞれのC分の消失速度 $\mathrm{R}^{\prime}$ を求めた。
Table 2. Experimental conditions.

\begin{tabular}{ll}
\hline Reaction Temperature & $1000,1250^{\circ} \mathrm{C}$ \\
Gas flow rate & $35 \mathrm{NI} / \mathrm{min}$ \\
Gas composition & $\mathrm{CO}_{2} / \mathrm{N}_{2}=25 / 75,55 / 45,85 / 15 \mathrm{vol} \%$ \\
Char flow rate & $1.0-4.3 \mathrm{~g} / \mathrm{min}(0.7-2.7 \mathrm{~g}-\mathrm{C} / \mathrm{min})$ \\
Solid-gas loading ratio & $0.02-0.07$ \\
\hline
\end{tabular}

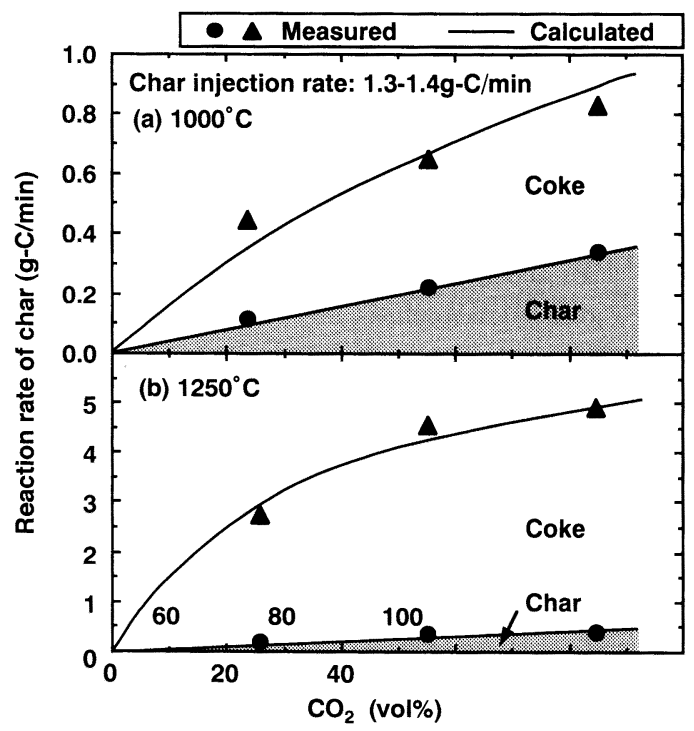

Fig. 2. Effect of $\mathrm{CO}_{2}$ on reaction rate of char.

$$
\begin{aligned}
& R_{\text {char }}^{\prime}=\left\{W_{l}^{\prime}\left(1-\omega_{V M I}^{\prime}-\omega_{\text {ash } l}^{\prime}\right)-W_{E}^{\prime}\left(1-\omega_{V M E}^{\prime}-\omega_{\text {ash } E}^{\prime}\right)\right. \\
& \left.-W_{H}^{\prime}\left(1-\omega_{V M H}^{\prime}-\omega_{\mathrm{ash} H}^{\prime}\right)\right\} / t \\
& R_{\mathrm{coke}}^{\prime}=\left(W_{I} \omega_{C I}-W_{E} \omega_{C E}\right) / t
\end{aligned}
$$

\section{$2 \cdot 2$ 試験結果}

Fig. 2(a)には反応温度 $1000^{\circ} \mathrm{C}$, チャーの吹込み量 $1.3-$ $1.4 \mathrm{~g}-\mathrm{C} / \mathrm{min}$ の時の, 供給ガス中 $\mathrm{CO}_{2}$ 濃度と $R^{\prime}$ との関係を示 す。 $R_{\text {char }}^{\prime}$ は $\mathrm{CO}_{2}$ とともに直線的に上昇するのに対して $R_{\mathrm{coke}}^{\prime}$ は高濃度側では飽和する傾向にある。Fig. 2(b)には同様に 反応温度が $1250^{\circ} \mathrm{C}$ の時の結果を示す。全体の傾向は $1000^{\circ} \mathrm{C}$ の場合と同様であるが，相対的にコークスの反応 量が著しく増大している。

Fig. 3(a)には反応温度 $1000^{\circ} \mathrm{C}$, 供給ガス中の $\mathrm{CO}_{2}$ 濃度が $55 \mathrm{vol} \%$ の時の，チャーの吹込み量と $R^{\prime}$ との関係を示す。 吹込み量の上昇とともに $R_{\mathrm{char}}^{\prime}$ は上昇し，高吹込み量側では 飽和する傾向が認められる。一方， $R_{\mathrm{char}}^{\prime}$ と $R_{\mathrm{coke}}^{\prime}$ の総和はほ ぼ一定であることから， $R_{\mathrm{coke}}^{\prime}$ は $R_{\mathrm{char}}^{\prime}$ と逆相関の関係にある ことが分かる。反応温度が $1250^{\circ} \mathrm{C}$ の場合も同様な傾向を 示すが(Fig. 3(b)), Fig. 2 と同様，コークスの反応量の増加 割合が大きい。

以上のような現象および因果関係の定量的な考察を可能 にするため，次章ではチャーの運動およびガス化反応を考 慮した新たな 1 次元微分収支モデルの構築を行った。 


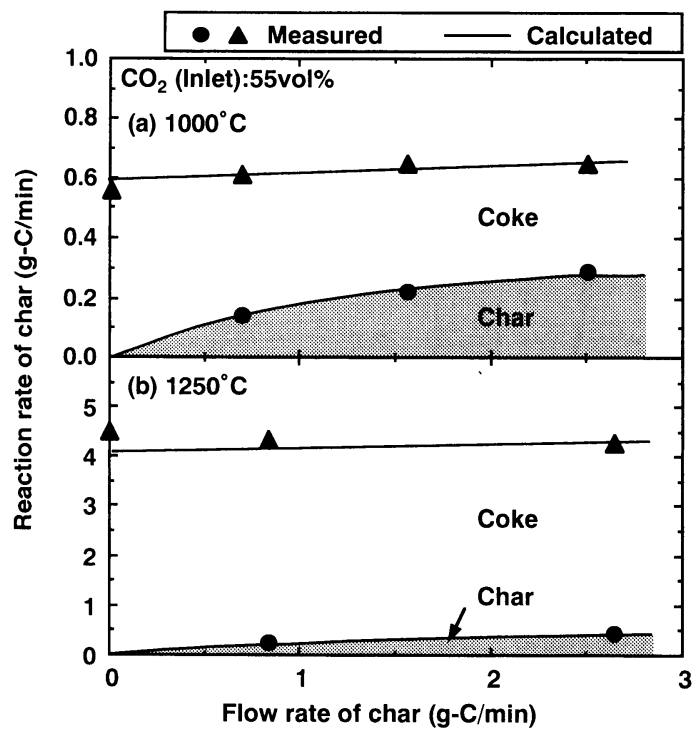

Fig. 3. Effect of char flow rate on reaction rate of char.

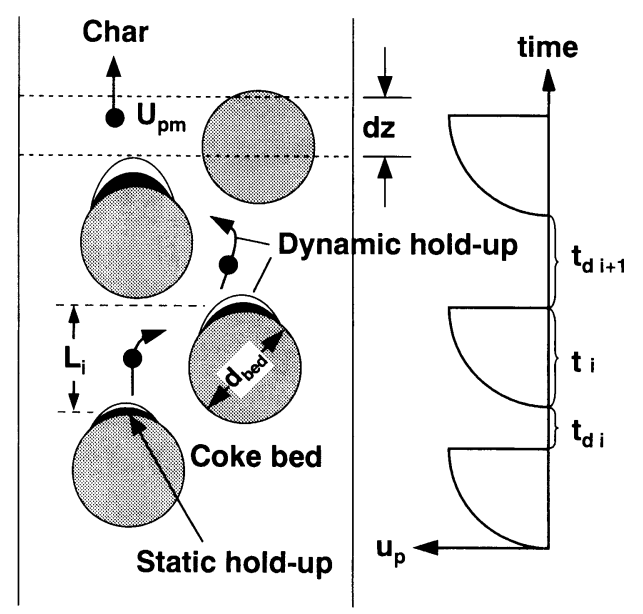

Fig. 4. Powder moving behavior model in a packed bed.

\section{3. 未燃チャーの充填層内移動・反応モデル}

\section{$3 \cdot 1$ 未燃チャーの充填層内における移動挙動}

いま, Fig. 4のような充填層内の1次元微分要素を考え る。下部から初期粒径 $d_{p o}$, 温度 $T_{p o}$ のチャーがガス組成 $y_{j}$, 温度 $T_{g o}$ のガスとともに固気比 $G_{p} / G_{g}$ で流入し, 均一に分 散した状態で上昇するとする。

ここで, 微粉粒子の充填層内上昇挙動の取り扱いとして は, 山岡ら ${ }^{5)}$, 柴田ら ${ }^{6)}$ のうに粉体を連続体として扱い, 粉とガス, ガスと充填粒子および粉と充填粒子の相互作用

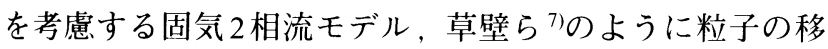
動と停止を考慮する粒子運動モデルなど多く提案されてい るが, 特定の粉体に着目して充填層内の平均移動速度を求 めるには不十分である。本研究では粉体の滞留時間分布の 実測から充填層内の平均移動速度を求めた有山ら ${ }^{9)} の$ 粒子 移動モデルを用いた。すなわち，有山らのコールドモデル 実験によれば，充填層内を移動する粉体はガス流に同伴し
て充填粒子間を飛翔する部分と充填物上に一時的に堆積 · 停止する部分から構成され，この停滞部の粉体は下から供 給される粉体によって順次更新される。したがって, 粉体 の平均移動速度 $U_{p m}$ は Fig. 4 に示すように, 局所空間の加 速期間における平均移動速度 $U_{p}$ と静的ホールドアップと して充填層内に停滞する時間 $t_{d} / L$ の双方の効果で決定され る。

$U_{p}$ の導出においては, 草壁らと同様 ${ }^{7)}$, 平均自由行程 $L_{i}$ を充填粒子径 $d_{\text {bed }}$ の $2 / 3$ とし, 飛散運動の平均速度として 計算した (( 3$) \sim(6)$ 式)。

$$
\begin{aligned}
d u_{p} / d t= & -g\left(\rho_{p}-\rho_{g}\right) / \rho_{p} \\
& +(3 / 4) C_{D} \rho_{g}\left|u_{g}-u_{p}\right|\left(u_{g}-u_{p}\right) / d_{p} \rho_{p}
\end{aligned}
$$

$$
\begin{aligned}
& L_{i}=\alpha d_{\text {bed }} \quad(\alpha=2 / 3) \\
& U_{p}=L_{i} / t_{i} \cdots \ldots \ldots \ldots \ldots \ldots
\end{aligned}
$$

また, 停滞時間 $t_{d} / L$ については, 粒子の移動時間 $1 / U_{p}$ と の比, すなわち $U_{p} \cdot t_{d} / L$ を固気比 SGRに対して整理した実 験結果 ${ }^{9)} よ り$ 導出した( 7 )式を用いた。

$$
U_{p} \cdot t_{d} / L=1.225 \mathrm{SGR}^{-0.548}
$$

よって, 層内の粉体の平均移動速度 $U_{p m}$ は $U_{p}$ と $t_{d} / L$ とから, 次の $(8)$ 式により求められる。

$$
1 / U_{p}+t_{d} / L=1 / U_{p m}
$$

(7), ( 8 )式より $U_{p m}$ と $U_{p}$ とは比例関係にあること，ただ し $U_{p}$ が一定なら固気比が高いほど $t_{d} / L$ が減少するため $U_{p m}$ は大となることが分かる。これは，高固気比の条件ほど下 方から供給される粉体によって充填粒子間に形成される停 滞層の更新が活発となり ${ }^{9)}$, 粉体の停滞時間 $\left(t_{d} / L\right)$ が相対的 に短くなることがその要因と考えられる。

\section{$3 \cdot 2$ 未燃チャーの素反応および総括反応速度 $R_{i}^{*}$}

本研究では，下記に示す未燃チャ一中の揮発分の揮発化 反応とチャーおよびコークスの $\mathrm{CO}_{2}$ によるガス化反応の 3 種類の反応を考慮した。

$$
\begin{array}{ll}
\mathrm{VM}(\mathrm{s}) \rightarrow \mathrm{VM}(\mathrm{g}) & R_{V M}^{*} \cdot \cdots \\
\mathrm{C}(\text { char })+\mathrm{CO}_{2} \rightarrow 2 \mathrm{CO} & R_{\text {char }}^{*} \cdot \cdots \\
\mathrm{C}(\text { coke })+\mathrm{CO}_{2} \rightarrow 2 \mathrm{CO} & R_{\text {coke }}^{*} \cdot \cdots
\end{array}
$$

揮発分の総括反応速度 $R_{V M}^{*}$ は(12)式で表した ${ }^{12)}$ 。チャー の総括反応速度 $R_{\mathrm{char}}^{*}$ につても, Fig. 2 の知見から $\mathrm{CO}_{2}$ 濃 度の 1 次式で表現することは妥当と考えられるため, 従来 と同様 ${ }^{12,13)}$ の(13)式を採用した。速度定数は境膜拡散速度 $k_{f}$ と化学反応速度 $k_{c}$ の混合律速を仮定した。このうち $k_{f}$ は 


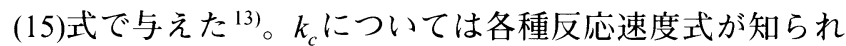
ているが 4,13-15)，使用炭種や測定条件によってばらつきが 大きい。よって本研究では(14)式のようにArrhenius型の速 度式として表現した上で, 頻度因子 $A$ と活性化エネルギー $E$ を高温反応試験の実測值から決定することとした。 $R_{\mathrm{coke}}^{*}$ についてはコークス粒子 1 個あたりの反応速度 $R_{\text {coke }}$ を用い て(16)式で表した。ここで， $R_{\text {coke }}$ は(17)式に示す Langmuir-Hinsohelwood型の速度式を採用し，粒径によって文 献值 ${ }^{16-20)}$ を使い分けた。

$$
\begin{aligned}
& R_{\mathrm{VM}}^{*}=N(\pi / 6) d_{p o}{ }^{3} \rho_{p o} k_{V o}\left(V^{*}-V\right) \exp \left(-E_{V M} / R T_{p}\right) \\
& R_{\text {char }}^{*}=N M_{c} \pi d_{p}^{2} /\left(1 / k_{c}+1 / k_{f}\right) C_{\mathrm{CO}_{2}} \\
& k_{c}=A \exp (-E / R T) \\
& k_{f}=D_{\mathrm{CO}_{2}}\left(2+0.6 \mathrm{Re}^{1 / 2} \mathrm{Sc}_{\mathrm{CO}_{2}}{ }^{1 / 3}\right) / d_{p} \cdots \\
& R_{\text {coke }}^{*}=\rho_{c} \omega_{c}(1-\varepsilon) x_{c} R_{\text {coke }} \\
& R_{\text {coke }}=\left\{k_{1} P_{\mathrm{CO}_{2}} /\left(1+k_{2} P_{\mathrm{CO}_{2}}+k_{3} P_{\mathrm{CO}}\right)\right\} \cdot\left(d_{c} / d_{c 0}\right)^{-n}
\end{aligned}
$$

$N$ は数密度であり，チャー（炭素分）の供給速度 $G_{\text {char }}$ を用 いて(18)式で与える。またチャーの単位重量あたりの見か けの反応速度 $R_{\text {char }}$ を(19)式で定義すると，(13)式の $R_{\text {char }}^{*}$ は (20)式と同等となる。(16)および(20)式からコークス，未燃 チャーいずれの場合も，R*は濃度項 $\left(\rho_{c} \omega_{c}(1-\varepsilon)\right.$ または $\left.G_{\text {char }} / U_{p m}\right)$ と反応速度項 $\left(R_{\text {coke }}\right.$ または $\left.R_{\text {char }}\right)$ の積で表現で きることが分かる。

$$
\begin{aligned}
& N=6 G_{\text {char }} / \pi d_{p}{ }^{3} \rho_{\text {char }} U_{p m} . \\
& R_{\text {char }}=6 R_{\text {char }}^{*} / \pi d_{p}^{3} \rho_{\text {char }} N . \\
& R_{\text {char }}^{*}=\left(G_{\text {char }} / U_{p m}\right) R_{\text {char }} .
\end{aligned}
$$

\section{$3 \cdot 3$ 物質およびエネルギー収支式}

本モデルは，ガス流束 $F_{x} ， 4$ 種類のガス成分 $\left(\mathrm{CO}_{2}, \mathrm{CO}\right.$, $\left.\mathrm{N}_{2}, \mathrm{VM}\right)$ の $ル$ 分率 $y_{j}$, チャーの粒径 $d_{p}$, 発生揮発分量 $V$, ガス温度 $T_{g}$, 粒子温度 $T_{p}$ および粒子速度 $U_{p m}$ の計 10 個の 変数から構成される。 $U_{p m}$ を除く物質およびエネルギー収 支に関する 9 本の微分方程式 $\left(d F_{x} / d z, y_{j} / d z(j=1,4), d d_{p} / d z\right.$, $\left.d V / d z, d T_{p} / d z, d T_{g} / d z\right)^{12)}$ および $U_{p m}$ を求める(3) (8)式を連立 させ, Runge-Kutta法で解いた。なお，高温反応試験では 加熱炉により常時 $T_{h}$ の温度が外部より与えられるので,

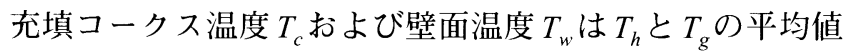
と考えた。また，チャーは密度 $\rho_{\text {char }}$ が一定で粒径のみが変 化するとした。装置全体における単位時間あたりの未燃 チャーおよびコークスの消費量 $R^{\prime}$ は(21)式より計算した。

$$
R_{k}^{\prime}=6 \times 10^{4} \int_{0}^{h} R_{k}^{*} \cdot S d z \quad(k=\text { char, coke })
$$

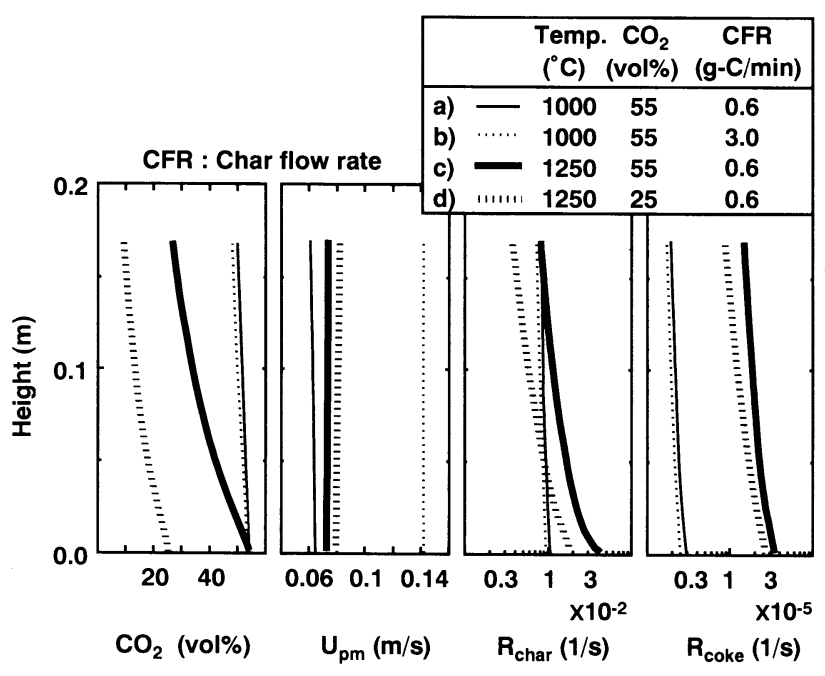

Fig. 5. Char moving and gasification behavior in packed bed (high temperature test furnace).

\section{4 未燃チャーの反応速度パラメーターの推算}

$3 \cdot 2$ 節で述べたように, (13)式における化学反応速度定 数 $k_{c}$ は未知のため, 実測值との比較により決定する必要が ある。決定方法としては以下のようにした。すなわち， (14)式の $A$ と $E$ の組合わせに対して第 1 近似を与えて前述 のモデルを実行し，(21)式で計算される $R_{k}^{\prime}$ と Fig. $2 ， 3$ にお ける全実測值との誤差が最小になるような組合わせを探索 法により求めた。このようにして得られた $k_{c}$ の推算式を (22)式に示す。本式は文献 ${ }^{14,15)}$ の報告值と近い。また本速 度式を適用して得られた $R^{\prime}$ の計算值を Fig. 2，3の図中に 示すが，実測值と良く対応していることから，(22)式の使 用は妥当だと思われる。

$$
k_{c}=5.1 \times 10^{4} \exp (-19900 / T)
$$

\section{$3 \cdot 5$ 高温反応試験における未燃チャーおよびコークスの 反応挙動解析}

Fig. 2，3における未燃チャーおよびコークスの反応挙動 を詳細に検討するため，上記モデルを用い，反応温度， チャ一吹込み量ならびに $\mathrm{CO}_{2}$ 濃度の影響について検討し た。計算条件を Fig. 5の四中 a)〜d)に示す。また同図には 計算結果の一例として, $\mathrm{CO}_{2}$ 濃度, $U_{p m}, R_{\mathrm{char}}$ および $R_{\mathrm{coke}}$ の反応装置高さ方向の変化を示す。

まず，反応温度を条件a)の $1000^{\circ} \mathrm{C}$ に対し， $1250^{\circ} \mathrm{C}$ まで 上昇させた $)$ について検討する。この場合に特徴的なこと は，装置入口での $R_{\text {char }}$ および $R_{\text {coke }}$ が大きく上昇する結果， 条件a)では僅かであったガス化反応が急速に進行するよう になることである。ただし，このガス化反応の進展に伴い $\mathrm{CO}_{2}$ 濃度が急速に低下するため，高さ方向に見ると反応は 抑制される方向にあり， $R_{\text {char }}, R_{\text {coke }}$ 共に減少していく。特 に $R_{\mathrm{char}}$ の低下は著しく, 装置出口では条件 $\left.\mathrm{a}\right)$ と同程度まで 低下する。この原因は，装置入口での $R_{\mathrm{char}}$ 值が条件 $\left.\mathrm{a}\right)$ の 4 倍程度の増加に留まったこと, 反応に伴う粒径低下により 
反応界面積が低下したことなどが挙げられる。また条件 c) では実ガス流速の增加により $U_{p m}$ が大となるため, 結局, (21)式から計算される $R_{\text {char }}^{\prime}$ は条件 a)の高々 2 倍程度までし か上昇できないと推測される。一方，コークスの場合，装 置入口部の $R_{\text {coke }}$ は絶対值としては小さいものの, 約 10 倍 まで上昇しており，かつ高さ方向全域にわたってこの差が 保存されている。また(16)式におけるコークスの濃度項は 約 $400 \mathrm{~kg}-\mathrm{C} / \mathrm{m}^{3}$ であり，(20)式の未燃チャ一のそれ（数 $\left.10 \mathrm{~g}-\mathrm{C} / \mathrm{m}^{3}\right)$ と比較して極端に大きいことを考慮すると， (21)式より計算される $R_{\text {coke }}^{\prime}$ は $R_{\text {char }}^{\prime}$ と同レベルの值を有し， かつ条件a)の約 10 倍となると予想される。Fig. 3において， 吹込み量 $0.6 \mathrm{~g} / \mathrm{min}$ の条件下で $1000^{\circ} \mathrm{C}$ から $1250^{\circ} \mathrm{C}$ への温度 上昇に伴う $R^{\prime}$ の変化量を調べてみると，それぞれ $1.7 ， 8$ 倍となり，上述の推定と比較的良く一致している。した がって，Fig. 3においてコークスの反応量増加割合が大と なるのは， $R_{\mathrm{coke}}$ の温度依存性が大きいことが主要因と考え られる。

次に，吹込み量の影響を検討するため条件 $\mathrm{a}$ )に対して吹 込み量を5倍に増加させたb)について見てみると， $R_{\text {char }}$ は a)とほとんど同一值となるが， $U_{p m}$ は2 倍程度にまで大幅 に増加するのが特徽である。これは(7)式に示したように， 固気比増加に伴いチャーの停滞時間 $t_{d} / L$ が減少するためで ある。ゆえに(20)式の $R_{\text {char }}^{*}$ は条件 a)の約 2.5 倍となり，さ らに高さ方向の変化も少ないので, $R_{\text {char }}^{\prime}$ 同様の数值にな ると推定される。Fig. 3 の反応温度が $1000^{\circ} \mathrm{C}$ の条件で吹込 み量が 0.6 と $3 \mathrm{~g} / \mathrm{min}$ の時の反応量を比較すると同じく 2.5 倍になっており，上記数值と一致している。したがって， Fig. 3で認められた吹込み量増大に伴うチャ一反応量の飽 和傾向は，(20)式の濃度項の変化に対応しているとみられ る。また，コークス反応量の相対的な低下はチャーのガス 化反応によって $\mathrm{CO}_{2}$ が速く消費される結果， $R_{\text {coke }}$ が小さく なったことが原因と推察される。

最後に $\mathrm{CO}_{2}$ 濃度を条件 d)に対して倍増させたc)について 見てみると， $R_{\text {char }}$ は高さ方向全域でほぼ倍となっているが, $R_{\text {coke }}$ は倍増には至っていない。これは, チャ一の反応速度 は(19)および(13)式からも分かるように $\mathrm{CO}_{2}$ 濃度に単純に 比例するのに対し，コークスでは(17)式に示す通り， $\mathrm{CO}_{2}$ とCOの両方の影響を受けることに起因する。すなわち， 条件 c)では $\mathrm{CO}_{2}$ 濃度の增加によりガス化反応は促進される が，同時に発生する COによって反応が阻害されることが， 前記 $R_{\text {coke }}$ が倍增に至らない要因と思われる。一方， $U_{p m} に$ ついて見ると，条件c)の方が僅かに小さくなっている。こ れは $\mathrm{CO}_{2}$ 濃度の上昇によって, 平均ガス密度が増し，見か け上固気比が低下したためである。このことは(20)式の濃 度項を多少なりとも上昇させる効果を持つ。以上より， (21)式から計算される $R^{\prime}$ は主として $R$ の変化に対応する。 したがって Fig. 2におけるチャーおよびコークスの反応挙 動の差は，このRの変化を反映したものと言える。

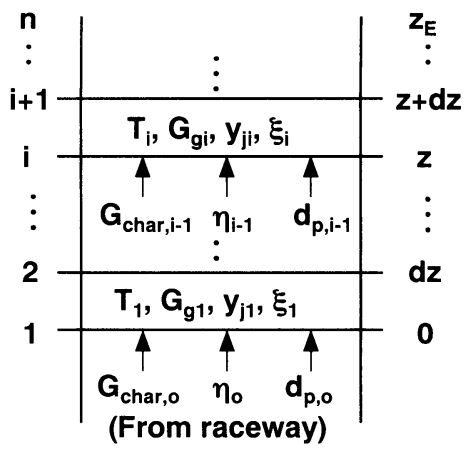

Fig. 6. Variables in packed bed of blast furnace.

以上のように，本モデルでは未燃チャーおよびコークス の反応挙動について高精度の解析が可能である。

\section{4. 高炉内における未燃チャーの移動・消費挙 動}

\section{$4 \cdot 1$ 解析方法}

実炉における未燃チャ一の移動・反応挙動の推定のため には，鉱石の還元による $\mathrm{CO}_{2}$ 発生を同時に考慮する必要が あるが，本研究では実炉におけるチャ一の消費可能量の推 算を目的としているため，チャーおよびコークスのガス化 反応と鉱石の還元の結果として決まる $\mathrm{CO}_{2} / \mathrm{CO}$ 濃度は与え られるものとして検討を進める。

いま，Fig. 6のようなレースウェイから排出された未燃 チャーが固体流量 $G_{\text {char, },}$ で流入する充填層を考える。ここ で, レースウェイ排出時の燃焼率を $\eta_{o}$, この時の粒子径 を $d_{p o}$ とする。さらに簡単のため, 任意のメッシュににおけ るチャーと充填層の温度は同一值 $T_{i}$ とし，またガス流速 $G_{g i}$, 組成 $y_{j i}$ は与えられると仮定すると, $3 \cdot 3$ 節で述べた 手順は大幅に簡略化される。すなわち，(23)式で定義され る単位長さあたりのチャ一の消費率 $\xi_{i}$ を用いれば，固体 流量 $G_{\text {char, },}$, 粒径 $d_{p i}$ および燃焼ガス化率 $\eta_{i}$ は(24) (26)式 から，チャーの存在量 UCR (Unburnt Char Rate)の分布は (27)式から求められる。また充填層の平均粒径 $d_{\mathrm{bed}}$ はコー クスと鉱石が均一混合しているとみなし(28)式で計算す る。以下の検討では $d_{c}$ および $d_{o}$ はそれぞれ $35 \mathrm{~mm}, 12 \mathrm{~mm}$ で一定にした。

$$
\begin{aligned}
& \xi_{i}=R_{\text {char }, i}^{*} / G_{\text {char }, i-1} \cdots \ldots \ldots \ldots \ldots \ldots \ldots \ldots \ldots . . . \\
& G_{\text {char }, i}=G_{\text {char }, o} \cdot \exp \left(-\sum_{i=1}^{i} \xi_{i} \Delta z\right) \\
& d_{p, i}=d_{p, o} \cdot \exp \left(-1 / 3 \sum_{i=1}^{i} \xi_{i} \Delta z\right) \\
& \eta_{i}=1-\left(1-\eta_{o}\right) G_{\text {char }, i} / G_{\text {char }, o} \cdots \\
& \mathrm{UCR}_{i}=\operatorname{PCR}\left(1-\omega_{\text {ash }}^{\prime}\right)\left(1-\eta_{i}\right) \cdots
\end{aligned}
$$




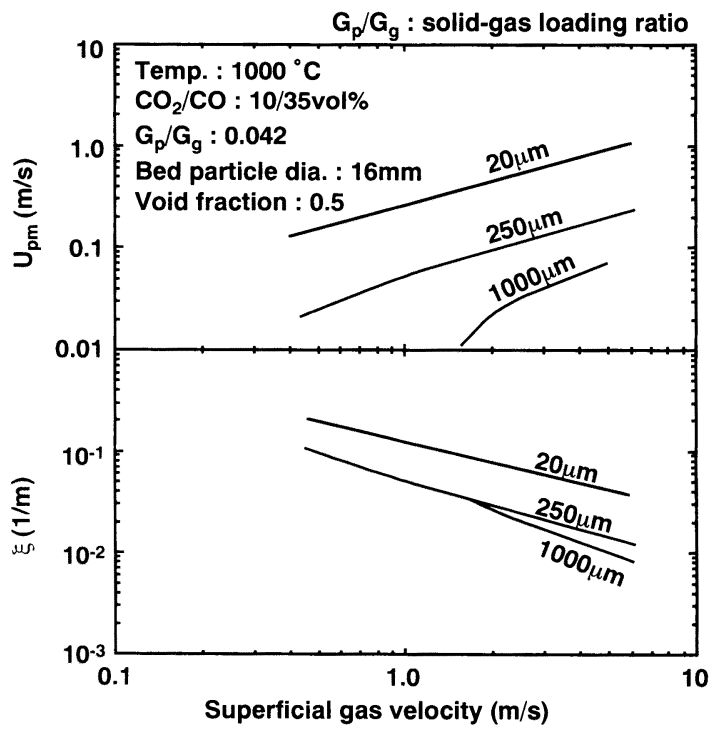

Fig. 7. Effect of superficial gas velocity on char moving and gasification behavior in actual blast furnace.

$$
d_{\text {bed }}=1 /\left\{x_{c} / d_{c}+\left(1-x_{c}\right) / d_{o}\right\}
$$

\section{$4 \cdot 2$ チャーの反応速度に及ぼす各種要因の検討}

前記モデルを用い，チャーの反応速度（単位長さあたり の消費率））に及ぼす各種要因の定量評価を実施した。

Fig. 7 は反応温度 $1000^{\circ} \mathrm{C}$, 圧力 $0.4 \mathrm{MPa}, \mathrm{CO}_{2} / \mathrm{CO}=10 / 35$

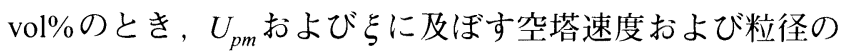
影響を示したものである。チャ一の流入条件は, PCRが $250 \mathrm{~kg} / \mathrm{t}$, レースウェイでの燃焼率 $\eta_{o}$ が $70 \%$ の条件を想定 し，固気比は 0.042 一定とした。本図より，粒径が $20 \mu \mathrm{m}$ 程度の微粒子であっても上昇速度はかなり小さく，実ガス 流速が実炉に近い $2 \mathrm{~m} / \mathrm{s}$ の条件でも 1 桁小さい $0.3 \mathrm{~m} / \mathrm{s}$ 程度 であることが分かる。よって, 高炉内の滞留時間は動力学 的な解析によって得られた值 ${ }^{10)} に$ 比べ，かなり長いと推察 される。さらに粒径が大となると上昇速度は低下し，粒径 が $1000 \mu \mathrm{m}$ 程度にまで達すると通常の高炉条件では上昇で きなくなる。一方, 消費率 $\xi$ は粒径が大きいほど低下した (Fig. 7下図)。このことは滞留時間増加による反応促進の 効果よりも，比表面積の低下による反応性低下の効果の方 が大きいことを示している。

Fig. 8には同様に固気比とガス流速の影響を示す。いず れのガス流速でも $U_{p m}$ は固気比の低下とともに小さくなっ ている。これは $3 \cdot 1$ 節で述べたように, 充填粒子間での停 滞時間が長くなったことによる。またこれに伴い $\xi は$ は明ら かに向上することから，高炉内では低固気比ほどチャーの 消費に有利であることが示唆される。

\section{$4 \cdot 3$ 高炉内における未燃チャーの高さ方向消費挙動の推 定}

未燃チャーの高炉高さ方向の消費挙動を推定するため, モデルケースとして Fig. 9の破線のような温度，ガス組成 および空隙率分布を想定した。ここで, 温度範囲としては

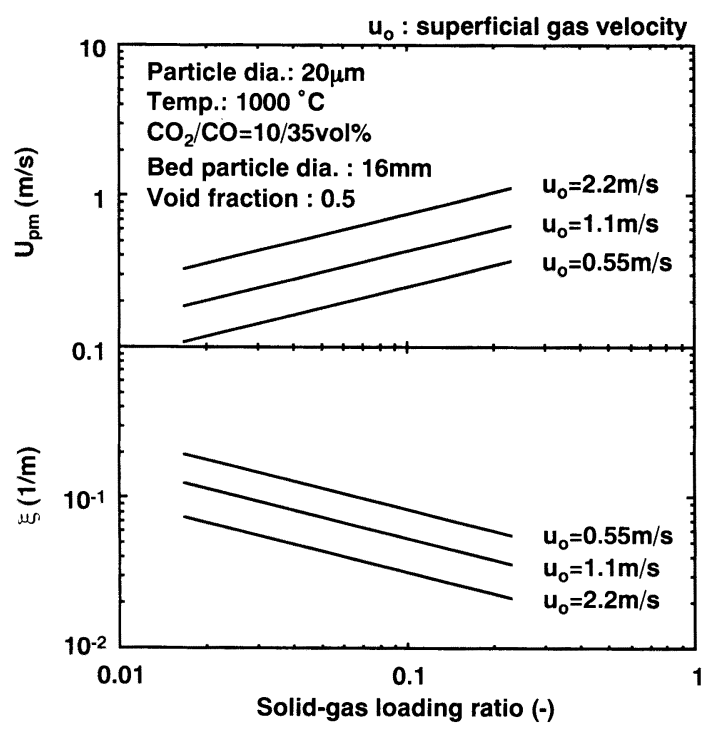

Fig. 8. Effect of solid--gas loading ratio on char moving and gasification behavior in actual blast furnace.

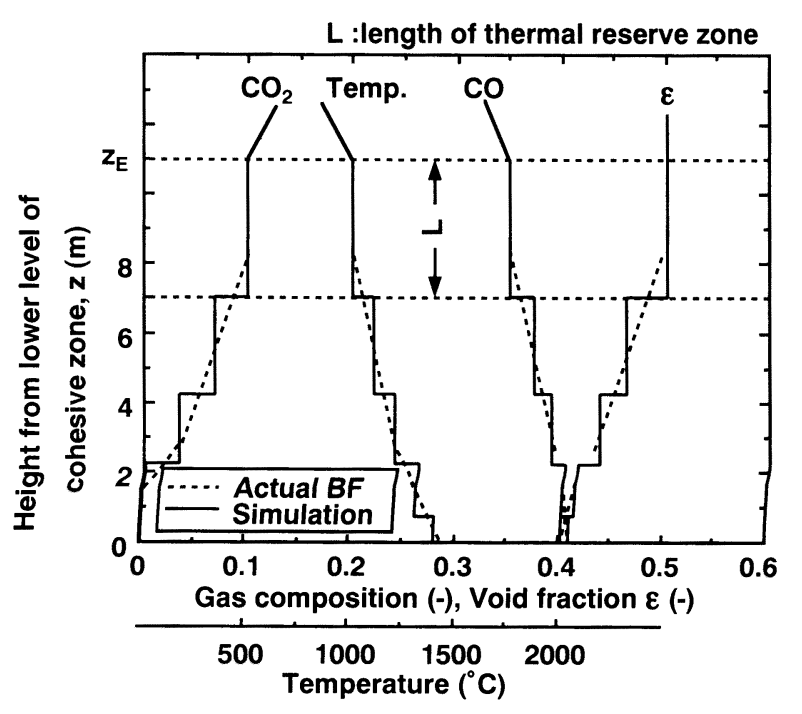

Fig. 9. Distribution of temperature and gas composition in blast furnace for mathematical simulation.

融着帯下面付近の $1400^{\circ} \mathrm{C}$ から温度保存帯の $1000^{\circ} \mathrm{C}$ までと し，全高は $z_{E}$, 温度保存帯長さ $L$ をパラメーターとした。 $\mathrm{CO}_{2}$ は $1300^{\circ} \mathrm{C}$ 付近から発生するとした。モデル計算では 高さ方向に約 20 分割し, 各分割要素間の温度等の諸量は, 図の実線に示すように階段状に変化するとした。炉内の空 塔速度は $1.1 \mathrm{~m} / \mathrm{s}$ で一定にした。本条件のもと，UCRに及 ぼすPCR（200および $250 \mathrm{~kg} / \mathrm{t} ） お よ ひ ゙ ~ \eta_{。}$ の影響について 調べた。なお，初期粒径は $\eta_{o}$ が $70 \%$ の時に $20 \mu \mathrm{m}$ とし， 他の $\eta_{0}$ の場合は発生チャーの粒子個数が不変であること を考虑して算出した。

Fig.10は $L=7 \mathrm{~m}$ とし，種々のPCR および $\eta_{o}$ の組合わせ によりレースウェイから発生する未燃チャーの量（ $z=0 に$ おける未燃チャ一量；以下では $\mathrm{UCR}_{o}$ と略す）を変化させ た時の，チャーの高さ方向の消費挙動を計算したものであ 


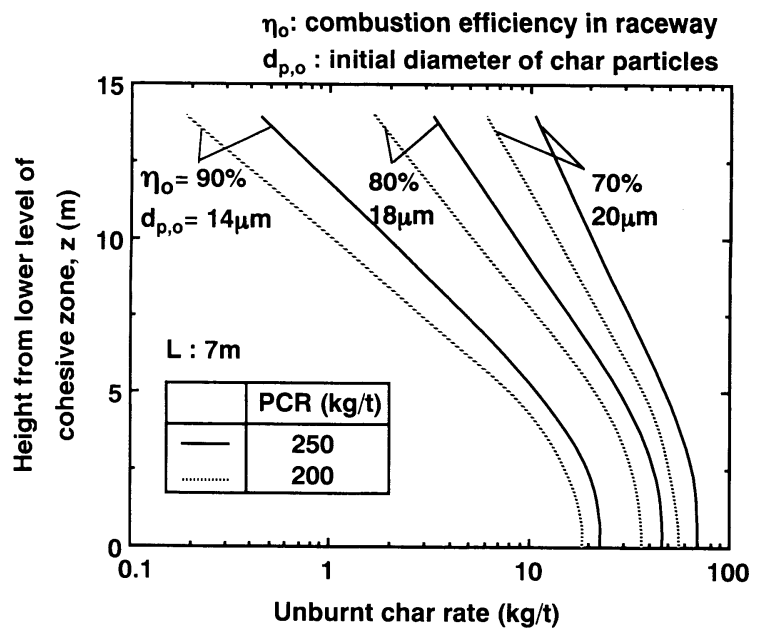

Fig. 10. Change in unburnt char rate along blast furnace height.

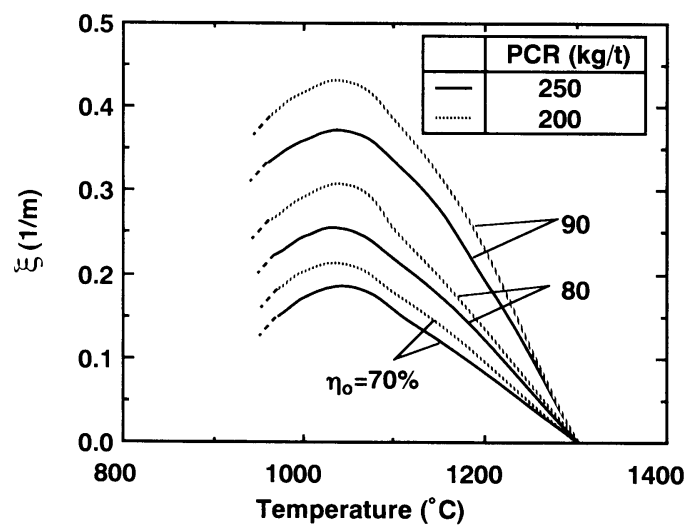

Fig. 11. Influence of temperature on consumption rate of unburnt char in blast furnace.

る。本図より, $\mathrm{UCR}_{o}$ が小 (低PCR, 高 $\eta_{o}$ ) ほど変化が急 であり, 温度保存帯出口における未反応チャ一量 $\left(z=z_{E}\right.$ における未燃チャー量; 以下, $\mathrm{UCR}_{E}$ と略す）は著しく低 下する傾向にある。この原因を明らかにするため, 各条件 における $\xi$ と温度の関係をプロットすると Fig.11が得られ る。いずれも $\xi$ は $1050^{\circ} \mathrm{C}$ 付近にピークを持つ曲線となっ ているが，これは(13)式からも分かるように，温度低下に 伴う化学反応速度減少の効果と $\mathrm{CO}_{2}$ 濃度上昇に伴う反応速 度促進の効果の相互作用によるものである。また $\mathrm{UCR}_{o}$ が

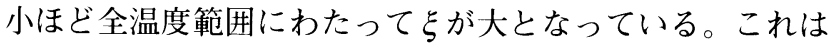
Fig. 8に示したように, 固気比の減少により粉体の平均上 昇速度が遅くなり，炉内の滞留時間が長くなったためと考 えられる。よって，Fig.10において低UCR。

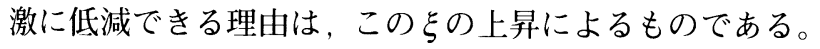

\section{4 末燃チャーの消費挙動からみたレースウェイ内燃焼 率の適正条件}

未燃チャーを灯頂から排出させない条件として，未燃 チャーの発生量が少なくとも高炉全体のカーボン収支から 決まるソルーションロス C量以下であることが必要であ る ${ }^{21)}$ 。Fig.12はこの関係を示したものであり，右上がりの

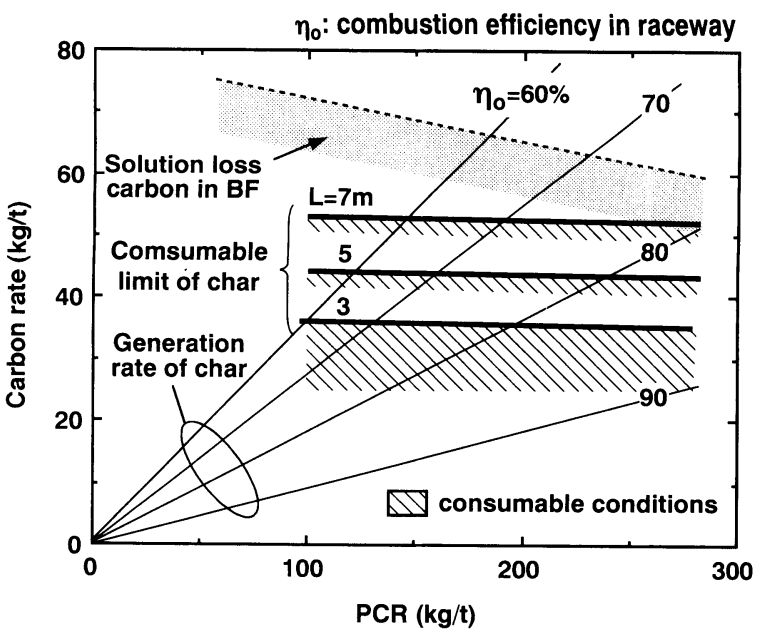

Fig. 12. Relationship between generation rate of char and consumable limit in blast furnace.

直線群がレースウェイでの燃焼率 $\eta_{0}$ に対応した未燃 チャー発生量を, 右下がりの破線が高炉でのソルーション ロス $\mathrm{C}$ 量の標準的な変化を表し，これらの交点が未燃 チャー発生量が高炉内での消費可能量を超えない限界の条 件を与える。例えば PCRが $200 \mathrm{~kg} / \mathrm{t}$ の場合， $\eta_{0}$ は $65 \%$ 以上， $250 \mathrm{~kg} / \mathrm{t}$ では $72 \%$ 以上であることが必要条件となる。しか しこの関係は, 発生したチャーの全量がソルーションロス 反応で消費されることが前提のため, チャーの消費速度を 過大に評価していることになる。

チャーの消費速度を考慮して炉内消費挙動を検討した Fig. 10 の場合, $\mathrm{UCR}_{E}$ が仮に $5 \mathrm{~kg} / \mathrm{t}$ 以下であることが，炉頂 から未燃チャーが発生しない条件と考えると，これを満足 する条件はPCRが $200 \mathrm{~kg} / \mathrm{t}$ では $\eta_{。}$ が約 $71 \%$ 以上（UCR。は $52 \mathrm{~kg} / \mathrm{t}$ 以下)，250 kg/t では 77\%以上（同 $54 \mathrm{~kg} / \mathrm{t}$ 以下）とな

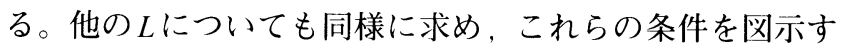
ると Fig.12の斜線部のようになる。これらの領域は先に示 したソルーションロス C量の範囲より大きく縮小してお り，同時に燃焼率の条件も厳しくなっているのが分かる。 $L$ ガ大きいほどこの条件は緩和されるが，UCR。 を概ね $50 \mathrm{~kg} / \mathrm{t}$ 以下に制御することが，炉頂からチャ一排出のない 順調な高炉操業を達成するための要件であると思われる。 この数值はPCRによらずほぼ一定と考えると, 必然的に 高PCR 時ほど $\eta_{o}$ を高める必要があることが分かる。

\section{5. 結言}

高炉下部コークス充填層におけるチャー粒子の平均滞留 時間およびチャーとコークスの競合ガス化反応を考虑した チャーの反応消費数式モデルを開発した。本数式モデルを 用いた解析により，以下の知見が得られた。

（1）高炉下部に打けるチャ一の平均上昇速度は, $20 \mu \mathrm{m}$ 程度の微細粒子であっても約 $0.3 \mathrm{~m} / \mathrm{s}$ と実ガス流速に 比べ約 1 桁小さく, よって滞留時間も比較的長い。 
（2）レースウエイから発生するチャー量が少ないほど 炉頂から未反応のまま排出されるチャ一量は著しく低減す る。これは，固気比が低いほど充填粒子間に堆積・停止す る粉体が，下方より供給される粉体によって更新されにく くなる結果, チャーの平均滞留時間が長くなり, 消費速度 が上昇するためである。

（3）炉頂から排出されるチャー量を一定值以下に抑え るためには，微粉炭吹込み比が高いほどレースウェイ内の 燃焼率を高める必要がある。

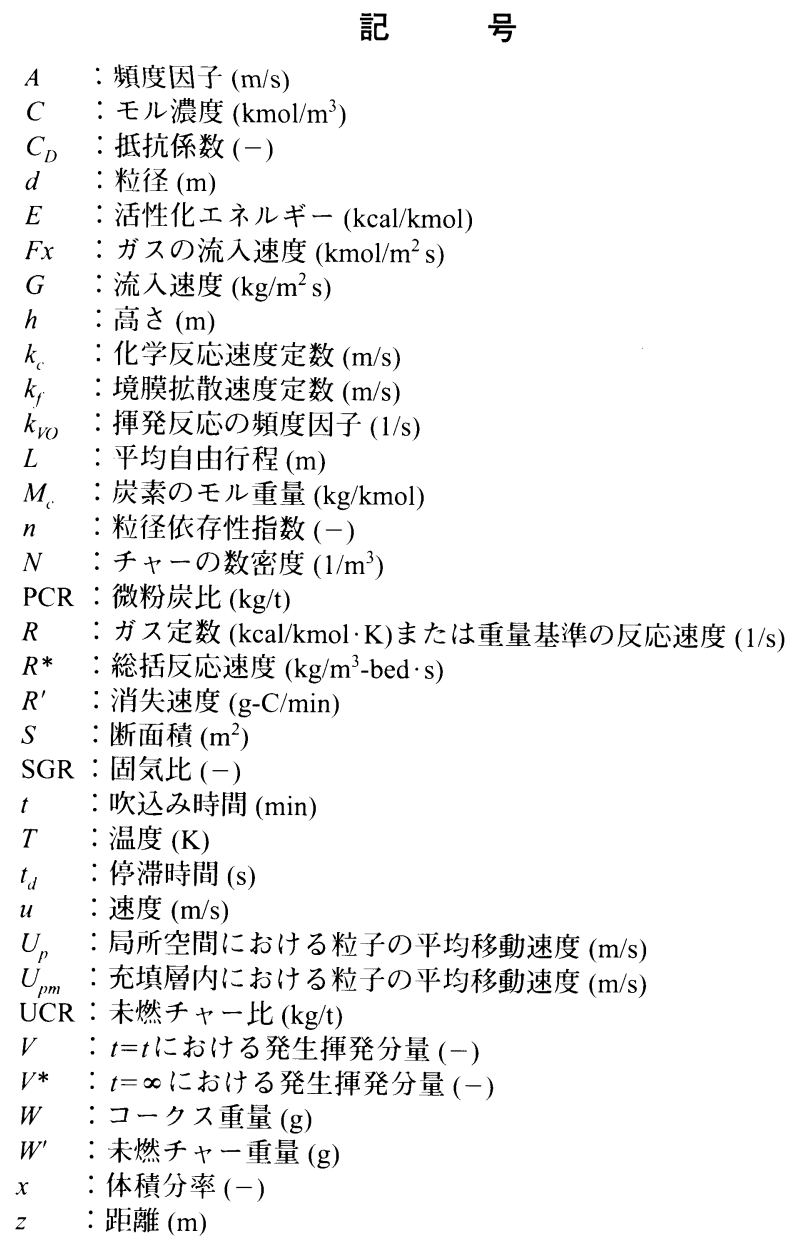

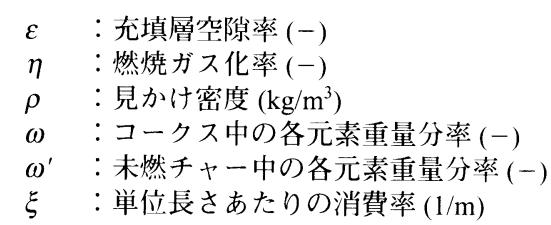

\section{添 え 字}

ash：灰分, bed：充填層, $c$ ：コークスまたは炭素, char：チャー (炭素分)， $E$ : 排出または終了時, $g$ : ガス, $H$ : ホールドアップ. $i ：$ メシュ番号， $I$ ：吹込みまたは初期， $j:$ ガス成分， $o$ : 基準ま たは鉱石, $p$ : 粒子, $V M$ : 揮発分, $w$ : 壁面

\section{文献}

1 ) T.Ariyama, M.Sato, Y.Yamakawa, Y.Yamada and M.Suzuki: Tetsu-toHagané, 80 (1994), 288.

2 ) K.Yamaguchi, H.Ueno, K.Tamura and Y.Yamada: Tetsu-to-Hagané, 78 (1992), 1214.

3 ) Y.Iwanaga: Tetsu-to-Hagané, 77 (1991), 71.

4 )上城親司, 稲田隆信, 岩永祐治：日本学術振興会製銑第 54 委 員会資料 No.1985, (1993).

5 ) H.Yamaoka: Tetsu-to-Hagané, 72 (1986), 44

6 ) K.Shibata, M.Shimizu, S.Inaba, R.Takahashi and J.Yagi: Tetsu-toHagané, 77 (1991), 55.

7 ) K.Kusakabe, T.Yamaki, S.Morooka and H.Matsuyama: Tetsu-toHagané, 77 (1991), 1407.

8 ) T.Sugiyama: Tetsu-to-Hagané, 82 (1996), 29

9 ) T.Ariyama, M.Sato and Y.Asakawa: Kagaku Kogaku Ronbunshu, 22 (1996), 171.

10) T.Inada, S.Kamijo, K.Katayama and T.Yamamoto: CAMP-ISIJ, 9 (1996), 22

11) M.Kuwabara, S.Takane, K.Sekido and I.Muchi: Tetsu-to-Hagané, 77 (1991), 1593.

12) M.Sato, R.Murai and T.Ariyama: Tetsu-to-Hagané, 82 (1996), 731

13) J.He, M.Kuwabara and I.Muchi: Tetsu-to-Hagané, 72 (1986), 1847.

14) P.J.Smith and L.D.Smoot: Combustion Sci. Technol., 23 (1980), 17.

15) M.Sijercic and K.Hanjalic: Combustion Sci. Technol., 97 (1994), 351.

16）近藤真一，原 行明，土屋 勝：日本学術振興会製銑第 54 委 員会資料 No.1309, (1972).

17) S.Kobayashi and Y.Omori: Tetsu-to-Hagané, 63 (1977), 1081

18) N.Miyasaka and S.Kondo: Tetsu-to-Hagané, 54 (1968), 1427.

19) M.Hatano, T.Miyazaki and Y.Iwanaga: Tetsu-to-Hagané, 65 (1979), 1365 .

20) S.Taguchi and K.Okabe: Kawasaki Steel Gihou, 2 (1970), 358

21) T.Ariyama: J. Jpn. Inst. Energy, 75 (1996), 880. 